dzie inspirację do dalszych poszukiwań naukowych w obrębie szeroko rozumianej kultury książki” (s. 9-10). Redaktorzy przedstawili oblicza współczesnej bibliologii.
Grażyna Gzella

Instytut Informacji Naukowej i Bibliologii Uniwersytetu Mikołaja Kopernika w Toruniu
W ydawać by się mogło, że konspiracyjne tomiki wierszy wydane w czasie II wojny światowej to temat dogłębnie zbadany i opisany. Podczas konferencji naukowych z cyklu „Kraków-Lwów: książki, czasopisma, biblioteki XIX i XX wieku", organizowanych w latach 1999-2013 przez Instytut Informacji Naukowej i Bibliotekoznawstwa Uniwersytetu Pedagogicznego im. KEN w Krakowie, prof. dr hab. Krzysztof Woźniakowski prezentował wyniki swoich dociekań oraz poszukiwań dotyczących głównie Generalnego Gubernatorstwa i ziem włączonych do Rzeszy w okresie okupacji hitlerowskiej 1939-1945. Ich większość została opublikowana w latach 2001-2011. Autor postanowił jednak zebrać je w jednym tomie zatytułowanym Marginalia i obrzeża. Szkice o zapomnianych konspiracyjnych tomikach poetyckich lat 1939-1945. Można dyskutować, czy to dobry pomysł. Praktyka prezentowania w formie książki wcześniej wydanych w różnych latach, rozproszonych w kilku lub kilkunastu miejscach artykułów nie jest nowa. Zabiegi takie spotykamy szczególnie

\section{Krzysztof Woźniakowski, Marginalia i obrzeża. Szkice o zapomnianych konspiracyjnych tomikach poetyckich lat 1939-1945, Opole: Wydawnictwo Naukowe Scriptorium 2013, 224 s., ISBN 978-83-62625-51-2}

DOI: http://dx.doi.org/10.12775/TSB.2015.009

często w okresie dwudziestolecia międzywojennego. Przykładowo tak ukazały się edycje cykli reportaży Konrada Wrzosa pt. Podróż po Polsce dzisiejszej, publikowanych od lutego do kwietnia 1933 r. na łamach krakowskiego „Ilustrowanego Kuriera Codziennego”, a wydane w tym samym roku w wersji książkowej Oko w oko z kryzysem okazały się bestsellerem. Także dziennikarza-odkrywcy Aleksandra Janty-Połczyńskiego „obroty reporterskie” zapisane w tomach: Patrzę na Moskwę i W głąb ZSRR (oba z roku 1933), Made in Japan, Odkrycie Ameryki, wyd. w roku 1935, w o rok starszych repor- 
tażach z Hollywood - Stolica srebrnej magii oraz w zapisie podróży do Chin i Japonii - Ziemia jest okrągła, a także w reportażach z podróży przez Indie, Afganistan, Birmę, Syjam, Indochiny, Chiny, Mongolię, Formozę do Japonii - Na kresach Azji, opublikowanych w roku 1939 - pierwotnie drukowane były na stronach różnorodnych czasopism dwudziestolecia: „Gazety Polskiej”, „Dwutygodnika Literackiego” (Kronika poznańska), „Dziennika Poznańskiego”, „Tęczy”, „Tygodnika Ilustrowanego”, „Radia”, „Ilustracji Polskiej". Przypomnieć wypada również późniejsze publikacje tego autora z okresu emigracyjnego, takie jak: Losy i Ludzie. Spotkania - Przygody - Studia 1931-1960 (Nowy Jork-Londyn 1961) czy Księga podróży, przygód i przypomnień (Londyn 1967), które były czytane z zapartym tchem przez polskich tułaczy na całym świecie.

Wracając do nowej edycji K. Woźniakowskiego, jest to zbiór dziesięciu szkiców na temat konspiracyjnego ruchu wydawniczego autorów zazwyczaj pomijanych $w$ antologiach i syntezach historycznoliterackich. Każdy z nich opatrzony jest ilustracjami kart tytułowych. Rozważania te uznać można za interesujące, tym bardziej że dotarcie do oryginalnych materiałów nastręczało wiele trudności, a autor sam przyznaje, że nie chce od nowa „«literacko» przewartościowywać ani proponować nowych hierarchii piśmiennictwa wo- jenno-okupacyjnego" (Od autora, s. 10). Zamysł wydaje się celny, ponieważ życie literackie tworzą zawsze różne poziomy, w tym także te z pogranicza grafomanii. Przede wszystkim wzbogacają naszą wiedzę na temat funkcjonowania podziemnej książki w skali mikro na opisywanym przez autora obszarze okupacyjnym.

Pierwszy szkic zatytułowany „O wolność" Tadeusza Ulewicza (1940) - pierwszy konspiracyjny zbiorek poetycki? rewiduje i uściśla wcześniejsze ustalenia Jerzego Święcha, Stanisława Sierotwińskiego oraz innych badaczy na temat wojennej twórczości literackiej późniejszego profesora zwyczajnego Uniwersytetu Jagiellońskiego, członka Polskiej Akademii Umiejętności, historyka literatury polskiej, przyjaciela Karola Wojtyły, zmarłego w 2012 r. Autor dotarł do dziesięciostronicowego maszynopisu powielanego o formacie $29,5 \times 20,5 \mathrm{~cm}$ - samodzielnego tomiku poetyckiego Ulewicza, wydanego w Krakowie w maju 1940 r. (który dzięki prywatnemu darowi posiada Biblioteka Jagiellońska od 1958 r.) pod pseudonimem Przemko Hreczecha, w nakładzie 100-150 egz. Autorem winiety był niepodpisany artysta plastyk Zygmunt Tokarzewski, a wydawcą - Antoni Pius Krzyżanowski. K. Woźniakowski zaproponował interpretację poszczególnych wierszy. Na podstawie obecnego stanu badań wysunął przypuszczenie, że może to 
być najwcześniejszy tomik poetycki, jaki ukazał się konspiracyjnie w czasie II wojny światowej w skali ogólnopolskiej.

Rozdział pt. Wojenne zabawy edytorskie Adama Włodka (1941-1944) omawia chałupniczo wytwarzane dokonania artystyczne dla dzieci i dorosłych krakowskiego poety, tłumacza (Rainera Marii Rilkego), późniejszego męża Wisławy Szymborskiej - Adama Włodka - w postaci 16 maszynopisowych edycji wierszy oraz tłumaczeń. Niektóre z nich powstały tylko w jednym egzemplarzu (1941-1943), w formie bibliofilskiej z własnymi rysunkami i układem graficznym, oprawione w płótno, czasem z tłoczonymi napisami na okładce, a także w formie zwykłej. Niemalże w komplecie zachowały się w Bibliotece Narodowej w Warszawie. Późniejsze publikacje Włodka wydane w serii „Biblioteka Poetycka Krakowa" (1944-1945) objęły 21 pozycji (każda skomponowana z kilkunastu utworów) w nakładzie 20-30 powielaczowych egzemplarzy. Badacz doszukał się debiutu A. Włodka w krakowskiej prasie gadzinowej („Fala”, „Ilustrowany Kurier Polski”), przypisując to młodzieńczemu brakowi wyobraźni, by skupić się na jego udziale w konspiracyjnym ruchu literackim Krakowa. K. Woźniakowski omówił także tematykę miłosno-erotyczną poszczególnych tomików, jak również przedstawił w czytelnej formie tabe- larycznej wykaz krakowskich konspiracyjnych edycji literackich A. Włodka z lat 1941-1944, który zawierał datę wydania, tytuł, format, objętość, technikę edycji, nakład oraz uwagi edytorskie.

Innym autorem wydobytym z całkowitego zapomnienia przez K. Woźniakowskiego jest Zdzisław Maria Okuljar, pseud. Zdzisław Katra z jego 71-stronicowym zbiorkiem erotyków zatytułowanych Gargantu (maj 1942), oprawionym w miękką tekturkę. Autor był pod wielkim wpływem Emila Zegadłowicza. Wiersze Okuljara były wydane w Rzeszy (Żywiec - Saybusch, małopolska część „pasa wschodniego” rejencji katowickiej), choć dla niepoznaki na stronie tytułowej podano Kraków jako niskonakładowy - 44 egz. bibliofilski private-druck. Drzeworytową okładkę wykonał artysta grafik Zygmunt Jaworski.

Bardzo ciekawe uwagi poczynił autor w szkicu na temat wojennych książeczek pisarki humorystyczno-satyrycznej Magdaleny Samozwaniec z lat 1942-1943, która okres II wojny światowej spędziła w rodzinnej „Kossakówce” w Krakowie. Cymelia okupacyjne autorki obejmowały pisane „dla chleba”, pełne humoru, parodii i fantazji wiersze dla dzieci (zbiór Królewna Śmieszka, 1942) oraz apolityczne, frywolne, bezpruderyjne fraszki dla dorosłych. Te drugie wydał na magistrackim powielaczu w liczbie 600 egz. przy- 
jaciel pisarki Zygmunt Niewidowski w 1943 r. (Fraszki Magdaleny Samozwaniec wiek XX). M. Samozwaniec samodzielnie zaprojektowała okładkę i stroną tytułową.

„Godziny czekania" Zbigniewa Mystkowskiego (1943): epizod z dziejów ksiq̨żki i literatury oflagowej w ujęciu K. Woźniakowskiego przypominają o jenieckiej twórczości literackiej. Do rzadko spotykanej formy wydawniczej, jako oddzielnie edytowanej książeczki, należy tomik nieprofesjonalnego literata w randze podporucznika, ,znanego tylko oflagowym kolegom" (s. 103), który ukazał się w 1943 r. w meklemburskim oflagu II w Neubrandenburgu. Zbiorek 12 wierszy został ozdobiony drzeworytami wykonanymi przez obozowego plastyka ppor. Wacława Bulzackiego. Były dwa wydania tego bibliofilskiego tomiku, który zdumiewał jakością wykonania w oflagowych warunkach, każdy liczył po 50 egz. Nakładu kolejnych trzech wydań autorowi nie udało się ustalić. Tematyka wierszy obejmowała obozowe realia „zadrutowanej” rzeczywistości.

Kolejny szkic wydobył z niepamięci dwa konspiracyjne, przepisane na maszynie tomiki poetyckie - Mój świat (1943) i Ucztę Aureliana (1944, 40 egz.) Tadeusza Chróścielewskiego (1943-1944), wydane w Mińsku Mazowieckim pod pseudonimem Tadeusza Rokitniaka. K. Woźniakowski otrzymał od autora kserokopie obu zbiorków, ponieważ nie ma ich w zbiorach bibliotecznych. Literat w czasie wojny założył w Mińsku Mazowieckim w 1942 r. podziemną grupę kulturalno-artystyczno-samokształceniowo-wydawniczą Koło Akademickie, działającą do lipca 1944 r. Wiersze z obu zbiorków poruszały różnorodną tematykę, zostały docenione przez krąg poetów związanych z warszawską „Sztuką i Narodem”.

Ciekawe wątki poznajemy w rozważaniach na temat konspiracyjnej działalności wydawniczej Zofii Jaremko-Pytowskiej na tle serii „Biblioteka Poetycka Krakowa" w okresie od lutego 1944 do stycznia 1945 r. w podwawelskim grodzie. Wszystkie tomiki różnych autorów tego przedsięwzięcia, będących pod wpływem twórczości Juliana Przybosia, były przepisywane na maszynie przez młodych literatów Adama Włodka i Tadeusza Jęczalika. Oni także byli autorami ręcznie sporządzanych kartonowych okładek. Nakład poszczególnych tomów wynosił od 5 do 50 egz. K. Woźniakowski zwizualizował 22 tomiki wydane w tej serii w czytelnej tabeli, obejmującej podstawowe dane bibliograficzne. Badacz uważa, że seria ta był ważna, ponieważ „była płaszczyzną wojennych wypowiedzi poetyckich Juliana Przybosia" (s. 145). Okupacyjnym zbiorkiem wierszy Z. Jaremko-Pytowskiej był debiutancki, niezbyt udany, na granicy grafomanii tomik sygnowany prawdziwym nazwiskiem pt. Rozdroża (1944). 
Poza obiegową wiedzą o wojennej kulturze literackiej znajdują się antologie lwowskiej grupy poetów amatorów „Żagiew” (1944), edytowane rzadko stosowaną w czasie II wojny światowej w wydawnictwach konspiracyjnych techniką odbitek fotograficznych maszynopisu. Założycielem grupy był Henryk Greb (pseud. Jan Obuch, Kajetan Szalej, Wiesław Jasień), który popularność wśród lwowian zdobył wierszami i fraszkami drukowanymi w gadzinówce „Gazecie Lwowskiej". Po zakończeniu współpracy z tą gazetą w 1943 r. utworzył Grupę Poetycką „Żagiew”, w skład której weszli poza nim: Bronisław Król (pseud. Andrzej Boruta), Mieczysław Miszewski (pseud. Jan Zawrat), Henryk Gruszkowski (pseud. Stefan Butrymowicz), Leszek Goliński (pseud. Krzysztof Mierzeja) i Maria Bielecka-Kasprowiczowa (pseud. Bożena Czerska). Fotoksiążeczki „Żagwi” - A imię jego jest 44 (marzec 1944), Przekroje (maj 1944) - sporne - Werble Lwowa (1944) były ilustrowane i ozdabiane przez współpracujących z grupą plastyków - Tadeusza Borowicza i Mieczysława Miszewskiego.

W Kraju Warty (Reichsgau Waterland) w lipcu 1944 r. Czesław Kubalik wydał pod swoim nazwiskiem w nakładzie 100 egz. tom poezji zatytułowany Głód przesytu. Z Karty informacyjnej załączonej do daru książeczki autora dla Biblioteki Narodowej (datowanej na 25 IX 1986 r.) wynika, że drukowana była ukradkiem przez polskich drukarzy zatrudnionych w niemieckiej drukarni w Poznaniu przy ul. Wielkiej (Breitenstrasse) 10. Liryki obejmują sentymentalne refleksje filozoficzne, wspomnieniowe, o miłości i kobietach, krajobrazowe. K. Woźniakowski nie szczędzi Kubalikowi krytyki, umiejscawiając jego debiut literacki w kręgu niedojrzałej grafomanii.

Szkic wieńczący publikację K. Woźniakowskiego dotyczy zbioru wierszy pt. Listy Aleksandry Mianowskiej, które są ostatnim konspiracyjnym krakowskim tomikiem poetyckim czasów okupacji hitlerowskiej, wydanym w nakładzie 36 egz. w styczniu 1945 r. przez tajną drukarnię Stefana Kamińskiego. Pozycja zawierała 26 utworów z lat 1940-1944, opisujących realia wojenno-okupacyjne wraz z konspiracyjną działalnością autorki (najważniejszy utwór kpiarski Hymn Montelupich, który stał się funkcjonującą publicznie pieśnią uwięzionych), także biograficzne rozterki autorki w postaci „listów bez adresu”, bezskutecznie poszukującej zaginionego w kampanii wrześniowej męża oraz wiersze poświęcone najbliższym.

Reasumując, przypomniane konspiracyjne działania wydawnicze okresu II wojny światowej w większości już opublikowane przez K. Woźniakowskiego w latach 2001-2013 (dokładny wykaz informacji o pierwodrukach 
znajduje się na s. 221-222) miał na celu zaakcentowanie udziału głównie Krakowa jako ośrodka podziemnej działalności literacko-wydawniczej w okresie okupacji hitlerowskiej. Autor sam nazwał je marginaliami i obrzeżami literatury, traktując jako księgoznawcze ciekawostki, repetycje i banały z pogranicza grafomanii, niektóre powstałe jako oddech od powagi czasu, w jakim przyszło im funkcjonować. Zamieszczony na końcu publikacji Indeks nazwisk, pseudonimów i kryptonimów zdecydowanie świadczy o metodolo- gicznej i warsztatowej kompetencji autora. Można zadać zasadnicze pytanie: do kogo skierowana jest ta niewielka książeczka? Myślę, że nie stracą przy niej czasu miłośnicy literatury, bibliolodzy, historycy oraz ci, których interesuje "czas pogardy” lat 1939-1945 w okupowanej Polsce.

Jolanta Chwastyk-Kowalczyk Instytut Bibliotekoznawstwa i Dziennikarstwa Uniwersytetu Jana Kochanowskiego w Kielcach 
